\title{
UPAYA MENINGKATKAN PRESTASI BELAJAR PENDIDIKAN AGAMA ISLAM DENGAN MENERAPKAN MODEL PEMBELAJARAN PAKEM PADA SISWA KELAS V SD NEGERI 200212 PADANGSIDIMPUAN TAHUN PELAJARAN 2015/2016
}

MELI ANNA LUBIS, S.Ag. NIP: 196305211992032005.

Email: melianna881@gmail.com

\begin{abstract}
ABSTRAK
Keberhasilan proses belajar mengajar di dalam kelas sangat ditentukan oleh strategi pembelajaran, bagaimanapun lengkap dan jelasnya komponen lain, tanpa diimplementasikan melalui strategi yang tepat, maka komponen-komponen tersebut tidak akan memiliki makna dalam proses pencapaian tujuan. Oleh karena itu setiap akan mengajar guru diharuskan untuk menerapkan strategi atau metode tertentu dalam pelaksanaan pembelajaran.

Penelitian ini berdasarkan permasalahan: (a) Bagaimanakah peningkatan prestasi belajar Pendidikan Agama Islam dengan diterapkannya model pembelajaran PAKEM? (b) Bagaimanakah pengaruh Model pembelajaran PAKEM terhadap motivasi belajar siswa?

Sedangkan tujuan dari penelitian ini adalah: (a) Ingin mengetahui peningkatan prestasi belajar siswa setelah diterapkannya strategi pembelajaran peningkatan kemampuan berpikir, (b) Ingin mengetahui pengaruh motivasi belajar siswa setelah diterapkan model pembelajaran PAKEM.

Penelitian ini menggunakan penelitian tindakan (action research) sebanyak tiga putaran. Setiap putaran terdiri dari empat tahap yaitu: rancangan, kegiatan dan pengamatan, refleksi, dan refisi. Sasaran penelitian ini adalah siswa kelas V SD. Data yang diperoleh berupa hasil tes formatif, lembar observasi kegiatan belajar mengajar.

Dari hasil analis didapatkan bahwa prestasi belajar siswa mengalami peningkatan dari siklus I sampai siklus III yaitu, siklus I (68,00\%), siklus II (80,00\%), siklus III $(92,00 \%)$.

Simpulan dari penelitian ini adalah model pembelajaran PAKEM dapat berpengaruh positif terhadap motivasi belajar siswa Kelas V SD, serta model pembelajaran ini dapat digunakan sebagai salah satu alternatif pembelajaran PAI.
\end{abstract}

Kata Kunci: belajar pai, pakem

\section{PENDAHULUAN}

Dalam kegiatan belajar mengajar yang

Guru berusaha menjadi pembimbing yang berlangsung telah terjadi interaksi yang baik dengan peranan yang arif dan bijaksana, bertujuan. Guru dan anak didiklah yang sehingga tercipta hubungan dua arah yang menggerakannya. Interaksi yang bertujuan itu disebabkan gurulah yang memaknainya dengan menciptakan lingkungan yang bernilai edukatif demi kepentingan anak didik dalam belajar. Guru ingin memberikan layanan yang terbaik bagi anak didik, dengan menyediakan lingkungan yang menyenangkan dan menggairahkan. harmonis antara guru dengan anak didik.

Ketika kegiatan belajar itu berproses, guru harus dengan ikhlas dalam bersikap dan berbuat, serta mau memahami anak didiknya dengan segala konsekuensinya. Semua kendala yang terjadi dan dapat menjadi penghambat jalannya proses belajar mengajar, baik yang berpangkal dari perilaku anak didik maupun yang bersumber 
Volume 3 Nomor 1, Halaman 1-81, Januari--Juni 2018

RISTEKDIK | Jurnal Bimbingan dan Konseling

P-ISSN: 2527-4244, E-ISSN : 2541-206X

dari luar anak didik, harus guru hilangkan, dan

Realisasi pencapaian tujuan tersebut, bukan membiarkannya. Karena keberhasilan terdapat kegiatan interaksi belajar mengajar belajar mengajar lebih banyak ditentukan oleh terutama yang terjadi di kelas. Dengan demikian, guru dalam mengelola kelas.

Dalam mengajar, guru harus pandai menggunakan pendekatan secara arif dan bijaksana, bukan sembarangan yang bisa merugikan anak didik. Pandangan guru terhadap anak didik akan menentukan sikap dan perbuatan Setiap guru tidak selalu mempunyai pandangan yang sama dalam menilai anak didik. Hal ini akan mempengaruhi pendekatan yang guru ambil dalam pengajaran.

Guru yang memandang anak didik sebagai pribadi yang berbeda dengan anak didik lainnya akan berbeda dengan guru yang memandang anak didik sebagai makhluk yang sama dan tidak ada perbedaan dalam segala hal. Maka adalah penting meluruskan pandangan yang keliru dalam menilai anak didik. Sebaiknya guru memandang anak didik sebagai individu dengan segala perbedaannya, sehingga mudah melakukan pendekatan dalam pengajaran.

Kualitas pembelajaran ditentukan oleh interaksi komponen-komponen dalam sistemnya. Yaitu tujuan, bahan ajar (materi), anak didik, sarana, media, metode, partisipasi masyarakat, performance sekolah, dan evaluasi pembelajaran (Moh, Shochib, 1998). Performance sekolah, dan evaluasi pembelajaran (Moh, Shochib, 1998). Optimalisasi komponen ini, menentukan kualitas (proses dan produk) pembelajaran. Upaya yang dapat dilakukan oleh pendidik adalah melakukan analisis tentang karakteristik setiap komponen dan mensinkronisasikan sehingga ditemukan konsistensi dan keserasian di antaranya untuk tercapainya tujuan pembelajaran. Karena pembelajaran mulai dari perencana, pelaksanaan dan evaluasinya senantiasa merujuk pada tujuan yang diharapkan untuk dikuasai atau dimiliki oleh anak didik baik instructional effect (sesuai dengan tujuan yang dirancang) maupun nurturrant effect (dampak pengiring) (Moch. Shochib: 1999). kegiatannya adalah bagaimana terjadi hubungan antara guru/bahan ajar yang didesain dan dengan anak didik. Interaksi ini merupakan proses komunikasi penyampaian pesan pembelajaran. Hal ini sejalan dengan yang dikemukakan Arief S Sadiman yang menyatakan proses belajar mengajar pada hakekatnya adalah proses interaksi yaitu proses penyampaian pesan melalui saluran media/teknik/ metode ke penerima pesan. (Arief S, Sadiman, dkk, 1996:13).

Sejalan dengan inovasi pembelajaran akhir-akhir ini termasuk di Sekolah Dasar, yaitu: PAKEM. Interaksi belajar mengajarnya menuntut anak didik untuk aktif, kreatif dan senang yang melibatkan secara optimal mental dan fisik mereka. Tingkat keaktifan, kreatifitas, dan kesenangan mereka dalam belajar merupakan rentangan kontinum dari yang paling rendah sampai yang paling tinggi. Tetapi idealnya pada kontinum yang tertinggi baik pelibatan aspek mental maupun fisik anak didik. Oleh karena itu, interaksi belajar mengajar dengan paradigma PAKEM menuntut anak:

(1) Berbuat

(2) Terlibat dalam kegiatan

(3) Mengamati secara visual

(4) Mencerap informasi secara verbal

Dengan demikian, interaksi belajar mengajar idealnya mampu membelajarkan anak didik berdasarkan problem based learning, authentic instruction, inquiry based learning, project based learning, service learning, and cooperative learning. Pola interaksi yang mampu mengemas hal tersebut dapat mengubah paradigma pembelajaran aktif menjadi paradigma pembelajaran reflektif.

Dengan interaksi pembelajaran reflektif dapat membuat anak didik untuk menjadikan hasil belajar sebagai referensi refleksi kritis tentang dampak ilmu pengetahuan dan teknologi terhadap masyarakat; mengasah kepedulian sosial, mengasah hati nurani, dan 
Volume 3 Nomor 1, Halaman 1-81, Januari--Juni 2018

RISTEKDIK | Jurnal Bimbingan dan Konseling

P-ISSN: 2527-4244, E-ISSN : 2541-206X

bertanggungjawab terhadap karirnya kelak.

Guru mengemban tugas yang berat untuk Kemampuan ini dimiliki anak didik, karena tercapainya tujuan pendidikan nasional yaitu dengan pola interaksi pembelajaran tersebut, meningkatkan kualitas manusia Indonesia, dapat membuat anak didik aktif dalam berfikir manusia seutuhnya yang beriman dan bertakwa (mind-on), aktif dalam berbuat (hand-on), terhadap Tuhan Yang Maha Esa, berbudi pekerti mengembangkan kemampuan bertanya, luhur, berkepribadian, berdisiplin, bekerja keras, mengembangkan kemampuan berkomunikasi, tangguh, bertanggung jawab, mandiri, cerdas dan dan membudayakan untuk memecahkan terampil serta sehat jasmani dan rohani, juga permasalahan baik secara personal maupun harus mampu menumbuhkan dan memperdalam sosial.

Agar hasil ini dapat optimal, guru dituntut untuk mengubah peran dan fungsinya menjadi fasilitator, mediator, mitra belajar anak didik, dan evaluator. Ini berarti, guru harus menciptakan interaksi pembelajaran yang demokratis dan dialogis antara guru dengan anak didik, dan anak didik dengan anak didik (Moh. Shochib: 1999; dan Paul Suparno dkk: 2001).

Dengan interaksi pembelajaran yang mengemas nilai-nilai tersebut dapat membuat pembelajaran lingking (link and math atau life skill) dan delinking (pemutusan lingkungan negatif), diversifikasi kurikulum, pembelajaran kontekstual, kurikulum berbasis kompetensi, dan otonomi pendidikan pada tingkat sekolah taman kanak-kanak dengan manajemen berbasis sekolah, dan bertujuan untuk mengupayakan fondasi dan mengembangkan anak untuk memiliki kemampuan yang utuh yang disebut: Pendidikan Anak Seutuhnya (PAS).

Pada dasarnya dalam kehidupan suatu bangsa, faktor pendidikan mempunyai peranan yang sangat penting untuk menjamin perkembangan dan kelangsungan hidup bangsa tersebut. Secara langsung maupun tidak langsung pendidikan adalah suatu usaha sadar dalam menyiapkan pertumbuhan dan perkembangan anak melalui kegiatan, bimbingan, pengajaran dan pelatihan bagi kehidupan dimasa yang akan datang. Tentunya hal ini merupakan tanggung jawab bersama antara pemerintah, anggota masyarakat dan orang tua. Untuk mencapai keberhasilan ini perlu dukungan dan partisipasi aktif yang bersifat terus menerus dari semua pihak. rasa cinta terhadap tanah air, mempertebal semangat kebangsaan dan rasa kesetiakawanan sosial. Sejalan dengan itu pendidikan nasional akan mampu mewujudkan manusia-manusia pembangunan dan membangun dirinya sendiri serta bertanggung jawab atas pembangunan bangsa. Depdikbud (1999).

Berhasilnya tujuan pembelajaran ditentukan oleh banyak faktor diantaranya adalah faktor guru dalam melaksanakan proses belajar mengajar, karena guru secara langsung dapat mempengaruhi, membina dan meningkatkan kecerdasan serta keterampilan siswa. Untuk mengatasi permasalahan di atas dan guna mencapai tujuan pendidikan secara maksimal, peran guru sangat penting dan diharapkan guru mampu menyampaikan semua mata pelajaran yang tercantum dalam proses pembelajaran secara tepat dan sesuai dengan konsep-konsep mata pelajaran yang akan disampaikan.

Dengan menyadari kenyataan tersebut di atas, maka dalam penelitian ini penulis mengambil judul "UPAYA MENINGKATKAN PRESTASI BELAJAR PENDIDIKAN AGAMA ISLAM DENGAN MENERAPKAN MODEL PEMBELAJARAN PAKEM PADA SISWA KELAS V SD NEGERI 200212 PADANGSIDIMPUAN TAHUN PELAJARAN 2015/2016." 


\section{METODE PENELITIAN}

Menurut pengertiannya penelitian tindakan adalah penelitian tentang hal-hal yang terjadi di masyarakat atau sekelompok sasaran, dan hasilnya langsung dapat dikenakan pada masyarakat yang bersangkutan (Arikunto, Suharsimi 2002:82). Ciri atau karakteristik utama dalam penelitian tindakan adalah adanya partisipasi dan kolaborasi antara peneliti dengan anggota kelompok sasaran. Penelitian tindakan adalah satu strategi pemecahan masalah yang memanfaatkan tindakan nyata dalam bentuk proses pengembangan inovatif yang dicoba sambil jalan dalam mendeteksi dan memecahkan masalah. Dalam prosesnya pihak-pihak yang terlibat dalam kegiatan tersebut dapat saling mendukung satu sama lain.

Sedangkan tujuan penelitian tindakan harus memenuhi beberapa prinsip sebagai berikut:

1. Permasalahan atau topik yang dipilih harus memenuhi kriteria, yaitu benarbenar nyata dan penting, menarik perhatian dan mampu ditangani serta dalam jangkauan kewenangan peneliti untuk melakukan perubahan.

2. Kegiatan penelitian, baik intervensi maupun pengamatan yang dilakukan tidak boleh sampai mengganggu atau menghambat kegiatan utama.

3. Jenis intervensi yang dicobakan harus efektif dan efisien, artinya terpilih dengan tepat sasaran dan tidak memboroskan waktu, dana dan tenaga.

4. Metodologi yang digunakan harus jelas, rinci, dan terbuka, setiap langkah dari tindakan dirumuskan dengan tegas sehingga orang yang berminat terhadap penelitian dapat mengecek setiap hipotesis dan pembuktiannya.

5. Kegiatan penelitian diharapkan dapat merupakan proses kegiatan yang berkelanjutan (on-going), mengingat bahwa pengembangan dan perbaikan terhadap kualitas tindakan memang tidak dapat berhenti tetapi menjadi tantangan sepanjang waktu. (Arikunto, Suharsimi, 2002:82-83).
Sesuai dengan jenis penelitian yang dipilih, yaitu penelitian tindakan, maka penelitian ini menggunakan model penelitian tindakan dari Kemmis dan Taggart (dalam Arikunto, Suharsimi, 2002:83), yaitu berbentuk spiral dari siklus yang satu ke siklus yang berikutnya. Setiap siklus meliputi planning (rencana), action (tindakan), observation (pengamatan), dan reflection (refleksi).

\section{HASIL PENELITIAN DAN PEMBAHASAN}

A. Hubungan Pembelajaran Model PAKEM dengan Ketuntasan Belajar

Suatu pokok bahasan atau sub pokok bahasan dianggap tuntas secara klasikal jika siswa yang mendapat nilai 65 lebih dari atau sama dengan $85 \%$, sedangkan seorang siswa dinyatakan tuntas belajar pada pokok bahasan atau sub pokok bahasan tertentu jika mendapat nilai minimal 65 .

1. Siklus I

a. Tahap Perencanaan

Pada tahap ini peneliti
mempersiapkan
perangkat
pembelajaran yang terdiri dari
rencana pelajaran 1, soal tes formatif
1 dan alat-alat pengajaran yang
mendukung. Selain itu juga
dipersiapkan lembar observasi
pengelolaan model pembelajaran
PAKEM, dan lembar observasi
aktivitas guru dan siswa.

b. Tahap Kegiatan dan Pelaksanaan

Pelaksanaan kegiatan belajar mengajar untuk siklus I dilaksanakan pada tanggal 4 Maret 2016 di Kelas V jumlah siswa 22 siswa. Dalam hal ini peneliti bertindak sebagai pengajar. Adapun proses belajar mengajar mengacu pada rencana pelajaran yang telah dipersiapkan. Pengamatan (observasi) dilaksanakan 
bersamaan dengan pelaksanaan belajar mengajar.

Pada akhir proses belajar mengajar siswa diberi tes formatif I dengan tujuan untuk mengetahui tingkat keberhasilan siswa dalam proses belajar mengajar yang telah dilakukan. Adapun data hasil penelitian pada siklus I adalah sebagai berikut.

Tabel 4.1. Rekapitulasi Hasil Tes Formatif Siswa Pada Siklus I

\begin{tabular}{|c|l|c|}
\hline No & \multicolumn{1}{|c|}{ Uraian } & Hasil \\
\hline 1 & $\begin{array}{l}\text { Nilai rata-rata tes } \\
\text { formatif }\end{array}$ & 70,00 \\
3 & $\begin{array}{l}\text { Jumlah siswa yang } \\
\text { tuntas belajar }\end{array}$ & 68,18 \\
\hline
\end{tabular}

Dari tabel di atas dapat dijelaskan bahwa dengan menerapkan pembelajaran model PAKEM diperoleh nilai rata-rata prestasi belajar siswa adalah 70,00 dan ketuntasan belajar mencapai $68,18 \%$ atau ada 15 siswa dari 22 siswa sudah tuntas belajar. Hasil tersebut menunjukkan bahwa pada siklus pertama secara klasikal siswa belum tuntas belajar, karena siswa yang memperoleh nilai $\geq 65$ hanya sebesar $68,18 \%$ lebih kecil dari persentase ketuntasan yang dikehendaki yaitu sebesar $85 \%$. Hal ini disebabkan karena siswa masih merasa baru dan belum mengerti apa yang dimaksudkan dan digunakan guru dengan menerapkan pembelajaran model PAKEM.

c. Refleksi

Dalam pelaksanaan kegiatan belajar mengajar diperoleh informasi dari hasil pengamatan sebagai berikut:

1) Guru kurang maksimal dalam memotivasi siswa dan dalam menyampaikan tujuan pembelajaran

2) Guru kurang maksimal dalam pengelolaan waktu

3) Siswa kurang aktif selama pembelajaran berlangsung

\section{d. Refisi}

Pelaksanaan kegiatan belajar mengajar pada siklus I ini masih terdapat kekurangan, sehingga perlu adanya revisi untuk dilakukan pada siklus berikutnya.

1) Guru perlu lebih terampil dalam memotivasi siswa dan lebih jelas dalam menyampaikan tujuan pembelajaran. Dimana siswa diajak untuk terlibat langsung dalam setiap kegiatan yang akan dilakukan.

2) Guru perlu mendistribusikan waktu secara baik dengan menambahkan informasiinformasi yang dirasa perlu dan memberi catatan.

3) Guru harus lebih terampil dan bersemangat dalam memotivasi siswa sehingga siswa bisa lebih antusias.

2. Siklus II

a. Tahap perencanaan

Pada tahap ini peneliti mempersiapkan perangkat pembelajaran yang terdiri dari rencana pelajaran 2 , soal tes formatif 2 dan alat-alat pengajaran yang mendukung.

b. Tahap kegiatan dan pelaksanaan

Pelaksanaan kegiatan belajar mengajar untuk siklus II dilaksanakan pada tanggal 11 Maret 2016 di Kelas V dengan jumlah 
siswa 22 siswa. Dalam hal ini peneliti bertindak sebagai pengajar. Adapun proses belajar mengajar mengacu pada rencana pelajaran dengan memperhatikan revisi pada siklus I, sehingga kesalahan atau kekurangan pada siklus I tidak terulang lagi pada siklus II. Pengamatan (observasi) dilaksanakan bersamaan dengan pelaksanaan belajar mengajar.

Pada akhir proses belajar mengajar siswa diberi tes formatif II dengan tujuan untuk mengetahui tingkat keberhasilan siswa dalam proses belajar mengajar yang telah dilakukan. Instrumen yang digunakan adalah tes formatif II. Adapun data hasil penelitian pada siklus II adalah sebagai berikut.

Tabel 4.2. Rekapitulasi Hasil Tes Formatif Siswa Pada Siklus II

\begin{tabular}{|c|l|c|}
\hline No & \multicolumn{1}{|c|}{ Uraian } & $\begin{array}{c}\text { Hasil } \\
\text { Siklus II }\end{array}$ \\
\hline 1 & $\begin{array}{l}\text { Nilai rata-rata tes } \\
\text { formatif }\end{array}$ & 77,73 \\
3 & $\begin{array}{l}\text { Jumlah siswa yang } \\
\text { tuntas belajar } \\
\text { Persentase ketuntasan } \\
\text { belajar }\end{array}$ & 79,01 \\
\hline
\end{tabular}

Dari tabel di atas diperoleh nilai rata-rata prestasi belajar siswa adalah 77,73 dan ketuntasan belajar mencapai $79,01 \%$ atau ada 17 siswa dari 22 siswa sudah tuntas belajar. Hasil ini menunjukkan bahwa pada siklus II ini ketuntasan belajar secara klasikal telah mengalami peningkatan sedikit lebih baik dari siklus I. Adanya peningkatan hasil belajar siswa ini karena setelah guru menginformasikan bahwa setiap akhir pelajaran akan selalu diadakan tes sehingga pada pertemuan berikutnya siswa lebih termotivasi untuk belajar. Selain itu siswa juga sudah mulai mengerti apa yang dimaksudkan dan diinginkan guru dengan menerapkan pembelajaran model PAKEM.

c. Refleksi

Dalam pelaksanaan kegiatan belajar diperoleh informasi dari hasil pengamatan sebagai berikut.

1) Memotivasi siswa

2) Membimbing siswa merumuskan kesimpulan/menemukan konsep

3) Pengelolaan waktu

d. Revisi Rancangan

Pelaksanaan kegiatan belajar pada siklus II ini masih terdapat kekurangan-kekurangan. Maka perlu adanya revisi untuk dilaksanakan pada siklus II antara lain:

1) Guru dalam memotivasi siswa hendaknya dapat membuat siswa lebih termotivasi selama proses belajar mengajar berlangsung.

2) Guru harus lebih dekat dengan siswa sehingga tidak ada perasaan takut dalam diri siswa baik untuk mengemukakan pendapat atau bertanya.

3) Guru harus lebih sabar dalam membimbing siswa merumuskan kesimpulan/menemukan konsep.

4) Guru harus mendistribusikan waktu secara baik sehingga kegiatan pembelajaran dapat berjalan sesuai dengan yang diharapkan.

5) Guru sebaiknya menambah lebih banyak contoh soal dan memberi soal-soal latihan pada siswa untuk dikerjakan pada setiap kegiatan belajar mengajar. 
3. Siklus III

a. Tahap perencanaan

Pada tahap ini peneliti
mempersiapkan
pembelajaran yang terdiri dari
rencana pelajaran 3, soal tes formatif
3 dan alat-alat pengajaran yang
mendukung.

b. Tahap kegiatan dan pengamatan

Pelaksanaan kegiatan belajar mengajar untuk siklus III dilaksanakan pada tanggal 18 Maret 2016 di Kelas V dengan jumlah siswa 22 siswa. Dalam hal ini peneliti bertindak sebagai pengajar. Adapun proses belajar mengajar mengacu pada rencana pelajaran dengan memperhatikan revisi pada siklus II, sehingga kesalahan atau kekurangan pada siklus II tidak terulang lagi pada siklus III. Pengamatan (observasi) dilaksanakan bersamaan dengan pelaksanaan belajar mengajar.

Pada akhir proses belajar mengajar siswa diberi tes formatif III dengan tujuan untuk mengetahui tingkat keberhasilan siswa dalam proses belajar mengajar yang telah dilakukan. Instrumen yang digunakan adalah tes formatif III. Adapun data hasil penelitian pada siklus III adalah sebagai berikut.

Tabel 4.3. Hasil Formatif Siswa Pada Siklus III

\begin{tabular}{|c|l|c|}
\hline No & \multicolumn{1}{|c|}{ Uraian } & $\begin{array}{c}\text { Hasil } \\
\text { Siklus } \\
\text { III }\end{array}$ \\
\hline 1 & Nilai rata-rata tes & 82,73 \\
2 & formatif & 20 \\
3 & Jumlah siswa yang & 86,36 \\
& tuntas belajar & \\
& $\begin{array}{l}\text { Persentase } \\
\text { ketuntasan belajar }\end{array}$ \\
\hline
\end{tabular}

Berdasarkan tabel di atas diperoleh nilai rata-rata tes formatif sebesar 82,73 dan dari 22 siswa telah tuntas sebanyak 20 siswa dan 2 siswa belum mencapai ketuntasan belajar. Maka secara klasikal ketuntasan belajar yang telah tercapai sebesar $86,36 \%$ (termasuk kategori tuntas). Hasil pada siklus III ini mengalami peningkatan lebih baik dari siklus II. Adanya peningkatan hasil belajar pada siklus III ini dipengaruhi oleh adanya peningkatan kemampuan guru dalam menerapkan pembelajaran model PAKEM sehingga siswa menjadi lebih terbiasa dengan pembelajaran seperti ini sehingga siswa lebih mudah dalam memahami materi yang telah diberikan.

c. Refleksi

Pada tahap ini akan dikaji apa yang telah terlaksana dengan baik maupun yang masih kurang baik dalam proses belajar mengajar dengan penerapan pembelajaran model PAKEM. Dari data-data yang telah diperoleh dapat diuraikan sebagai berikut:

1) Selama proses belajar mengajar guru telah melaksanakan semua pembelajaran dengan baik. Meskipun ada beberapa aspek yang belum sempurna, tetapi persentase pelaksanaannya untuk masing-masing aspek cukup besar.

2) Berdasarkan data hasil pengamatan diketahui bahwa siswa aktif selama proses belajar berlangsung.

3) Kekurangan pada siklus-siklus sebelumnya sudah mengalami perbaikan dan peningkatan sehingga menjadi lebih baik.

4) Hasil belajar siswa pada siklus III mencapai ketuntasan. 


\section{d. Revisi Pelaksanaan}

Pada siklus III guru telah menerapkan pembelajaran model PAKEM dengan baik dan dilihat dari aktivitas siswa serta hasil belajar siswa pelaksanaan proses belajar mengajar sudah berjalan dengan baik. Maka tidak diperlukan revisi terlalu banyak, tetapi yang perlu diperhatikan untuk tindakan selanjutnya adalah memaksimalkan dan mempertahankan apa yang telah ada dengan tujuan agar pada pelaksanaan proses belajar mengajar selanjutnya penerapan model pembelajaran PAKEM dapat meningkatkan proses belajar mengajar sehingga tujuan pembelajaran dapat tercapai.

\section{B. Pembahasan}

1. Ketuntasan Hasil Belajar Siswa

Melalui hasil penelitian ini menunjukkan bahwa pembelajaran model PAKEM memiliki dampak positif dalam meningkatkan prestasi belajar siswa. Hal ini dapat dilihat dari semakin mantapnya pemahaman siswa terhadap materi yang disampaikan guru (ketuntasan belajar meningkat dari siklus I, II, dan III) yaitu masing-masing $68,18 \%, 79,01 \%$, dan $86,36 \%$. Pada siklus III ketuntasan belajar siswa secara klasikal telah tercapai.

2. Kemampuan Guru dalam Mengelola Pembelajaran

Berdasarkan analisis data, diperoleh aktivitas siswa dalam proses belajar mengajar dengan menerapkan model pembelajaran PAKEM dalam setiap siklus mengalami peningkatan. Hal ini berdampak positif terhadap prestasi belajar siswa yaitu dapat ditunjukkan dengan meningkatnya nilai rata-rata siswa pad setiap siklus yang terus mengalami peningkatan.

3. Aktivitas Siswa Dalam Pembelajaran

Berdasarkan analisis data, diperoleh aktivitas siswa dalam proses pembelajaran PAI pada pokok bahasan kisah nabi Ibrahim a.s, dan nabi Ismail a.s dengan model pembelajaran PAKEM yang paling dominan adalah, mendengarkan/memperhatikan

penjelasan guru, dan diskusi antar siswa/antara siswa dengan guru. Jadi dapat dikatakan bahwa aktivitas siswa dapat dikategorikan aktif.

Sedangkan untuk aktivitas guru selama pembelajaran telah melaksanakan langkah-langkah kegiatan belajar mengajar dengan menerapkan pengajaran konstekstual model pengajaran berbasis masalah dengan baik. Hal ini terlihat dari aktivitas guru yang muncul di antaranya aktivitas membimbing dan mengamati siswa dalam menemukan konsep, menjelaskan materi yang sulit, memberi umpan balik/evaluasi/tanya jawab dimana prosentase untuk aktivitas di atas cukup besar.

\section{SIMPULAN}

Berdasarkan hasil penelitian yang telah dipaparkan selama tiga siklus, hasil seluruh pembahasan serta analisis yang telah dilakukan dapat disimpulkan sebagai berikut:

1. Model pembelajaran PAKEM dapat meningkatkan kualitas pembelajaran PAI.

2. Pembelajaran model PAKEM memiliki dampak positif dalam meningkatkan prestasi belajar siswa yang ditandai dengan peningkatan ketuntasan belajar siswa dalam setiap siklus, yaitu siklus I $(68,18 \%)$, siklus II $(79,01 \%)$, siklus III $(86,36 \%)$.

3. Model pembelajaran PAKEM dapat menjadikan siswa merasa dirinya mendapat perhatian dan kesempatan 
untuk menyampaikan pendapat, gagasan, Nur, Moh. 2001. Pemotivasian Siswa untuk ide dan pertanyaan.

4. Siswa dapat bekerja secara mandiri maupun kelompok, serta mampu mempertanggungjawabkan segala tugas individu maupun kelompok.

5. Penerapan pembelajaran model PAKEM mempunyai pengaruh positif, yaitu dapat meningkatkan motivasi belajar siswa.

\section{DAFTAR PUSTAKA}

Ali, Muhammad. 1996. Guru Dalam Proses Belajar Mengajar. Bandung: Sinar Baru Algesindon.

Arikunto, Suharsimi. 1993. Manajemen Mengajar Secara Manusiawi. Jakarta: Rineksa Cipta.

Arikunto, Suharsimi. 2001. Dasar-dasar Evaluasi Pendidikan. Jakarta: Bumi Aksara.

Arikunto, Suharsimi. 2002. Prosedur Penelitian Suatu Pendekatan Praktek. Jakarta: Rineksa Cipta.

Azhar, Lalu Muhammad. 1993. Proses Belajar Belajar. Surabaya: University Press. Univesitas Negeri Surabaya.

Rustiyah, N.K. 1991. Strategi Belajar Mengajar. Jakarta: Bina Aksara.

Sardiman, A.M. 1996. Interaksi dan Motivasi Belajar Mengajar. Jakarta: Bina Aksara.

Soekamto, Toeti. 1997. Teori Belajar dan Model Pembelajaran. Jakarta: PAU-PPAI, Universitas Terbuka.

Sukidin, dkk. 2002. Manajemen Penelitian Tindakan Kelas. Surabaya: Insan Cendekia.

Surakhmad, Winarno. 1990. Metode Pengajaran Nasional. Bandung: Jemmars.

Suryosubroto, B. 1997. Proses Belajar Mengajar di Sekolah. Jakarta: PT. Rineksa Cipta.

Syah, Muhibbin. 1995. Psikologi Pendidikan, Suatu Pendekatan Baru. Bandung: Remaja Rosdakarya.

Usman, Moh. Uzer. 2001. Menjadi Guru Profesional. Bandung: Remaja Rosdakarya. Mengajar Pendidikan. Jakarta: Usaha Nasional.

Daroeso, Bambang. 1989. Dasar dan Konsep Pendidikan Moral Pancasila. Semarang: Aneka Ilmu.

Djamarah, Syaiful Bahri. 2002. Strategi Belajar Mengajar. Jakarta: Rineksa Cipta.

Djamarah, Syaiful Bahri. 2002. Psikologi Belajar. Jakarta: Rineksa Cipta.

Hadi, Sutrisno. 1982. Metodologi Research, Jilid 1. Yogyakarta: YP. Fak. Psikologi UGM.

Hamalik, Oemar. 2002. Psikologi Belajar dan Mengajar. Bandung: Sinar Baru Algesindo.

Hasibuan K.K. dan Moerdjiono. 1998. Proses Belajar Mengajar. Bandung: Remaja Rosdakarya.

Margono. 1997. Metodologi Penelitian Pendidikan. Jakarta. Rineksa Cipta.

Masriyah. 1999. Analisis Butir Tes. Surabaya: Universitas Press.

Ngalim, Purwanto M. 1990. Psikologi Pendidikan. Bandung: PT. Remaja Rosdakarya. 